\title{
Resiliensi pada Remaja Tunadaksa yang Mengalami Bullying
}

\author{
MELINDA OVIYANTI \& WIWIN HENDRIANI*
}

Departemen Psikologi Pendidikan dan Perkembangan, Fakultas Psikologi Universitas Airlangga

\begin{abstract}
ABSTRAK
Penelitian ini bertujuan untuk mengetahui gambaran resiliensi yang ditinjau dari teori Grotberg. Sumber resiliensi, sebagaimana dinyatakan oleh Grotberg, dibagi menjadi 3 dimana terdapat sumber $I$ am, I have, dan I can. Metode penelitian ini menggunakan pendekatan kualitatif dengan tipe penelitian studi kasus intrinsik. Pemilihan partisipan menggunakan purposive sampling dengan metode screening resilience. Partisipan berjumlah 3 remaja perempuan yang terdiri dari seorang remaja berusia 14 tahun dan 2 remaja berusia 15 tahun. Proses pengambilan data menggunakan wawancara dan dianalisis menggunakan analisis tematik theory-driven. Hasil penelitian ini menunjukkan bahwa ketiga partisipan memiliki bentuk coping stress yang berbeda untuk menuju resiliensi. Partisipan 3 memiliki resiliensi paling menonjol di antara partisipan lain, dan meskipun terdapat banyak adversity yang dialami, partisipan 3 menunjukkan resiliensi yang tinggi melalui indikator I am.
\end{abstract}

Kata kunci: remaja, tunadaksa, perundungan, resiliensi

\section{ABSTRACT}

This study aimed to overview the Grotberg's resilience theory. The source of resilience, as stated by Grotberg, is divided into 3 which include "I am", "I have", and "I can". This was qualitative intrinsic case study. The participants were chosen by purposive sampling with resilience screening methods. There were 3 female adolescent participants; one aged 14 years old and the other two aged 15 years old. The data were collected using interviews and analyzed using theory-driven thematic analysis. The result of this study indicated that the participants had different forms of coping stress towards resilience. Participant 3 was the most prominent among other participants, and although participant 3 experienced adversity, the participant demonstrated a high resilience as evidenced through the "I am" indicator.

Key words: adolescents, disabilities, bullying, resilience

INSAN Jurnal Psikologi dan Kesehatan Mental, 2020, Vol. 5(1), 13-20, doi: 10.20473/jpkm.v5i12020.13-20 Dikirimkan: 30 Januari 2020 Diterima: 1 Mei 2020 Diterbitkan: 26 Juni 2020

Editor: Rosatyani Puspita Adiati

*Alamat korespondensi: Fakultas Psikologi Universitas Airlangga, Kampus B Universitas Airlangga Jalan Airlangga 4-6 Surabaya 60286. Pos-el: wiwin.hendriani@psikologi.unair.ac.id 


\section{P E N D A H U L U A N}

Kasus perundungan yang kerap terjadi dalam dunia pendidikan di Indonesia kian memprihatinkan. Indonesia mendapat peringkat kedua terbesar setelah Jepang pada kasus perundungan atau kekerasan terhadap anak di sekolah (Indra, 2015). Data Global School-based Student Health Survey (GSHS) menunjukkan bahwa kasus perundungan di Indonesia mengalami peningkatan sejak tahun 2007. Sekitar 40 persen murid berusia 13-15 tahun di Indonesia melaporkan telah diserang secara fisik selama 12 bulan terakhir di sekolah mereka. Laporan Komisi Perlindungan Anak Indonesia (KPAI) tahun 2013 menunjukkan bahwa terdapat 1.051 anak korban perundungan di Indonesia atau setara 70 persen pada rentang usia 8 - 12 tahun.

Penelitian mengenai perundungan yang dilakukan oleh (Magfirah, 2008) di Yogyakarta menunjukkan bahwa kasus perundungan di tingkat SMP dan SMA termasuk yang paling tinggi yaitu sebanyak 70,65 persen bila dibandingkan dengan Jakarta dan Surabaya. Bentuk perundungan yang terjadi didominasi oleh perundungan secara fisik. Dalam penelitian tersebut, dijelaskan bahwa pada bulan Mei hingga Oktober 2008, perundungan secara fisik adalah yang paling banyak terjadi di dua SMA negeri dan SMA swasta di Yogyakarta. Bentuk perundungan tersebut antara lain dihukum push up atau berlari, dipukul, dijegal atau diinjak kaki, dan dilempari dengan barang. Selain itu, perundungan secara psikologis juga dialami oleh siswa, seperti difitnah atau digosipkan, dipermalukan di depan umum, dihina atau dicaci, dan disoraki.

Kasus perundungan juga dialami oleh individu disabilitas; individu yang sangat rentan untuk menjadi korban perundungan di tengah lingkungannya. Hal itu terjadi baik di dalam maupun di luar negeri. Salah satu contoh korban dari luar negeri adalah Tyler Long yang merupakan seorang siswa di Murray County High School, Negara bagian Georgia, Amerika Serikat. Tyler memilih bunuh diri dengan cara gantung diri di kamarnya pada 17 Oktober 2009. Hal itu ia lakukan setelah mendapatkan perundungan dari teman-teman sekelasnya. Ia dihina baik lewat ucapan maupun tindakan. Ada yang mengatakan dia aneh, gay, bahkan ada yang meludahi makan siangnya. Akhirnya, pemuda yang mengidap autism asperger ini memilih mengakhiri hidupnya (News, 2009). Sementara di Indonesia, salah satu kasus perundungan pada murid dengan disabilitas dialami oleh Renaldi yang terjadi di kota Banyuwangi. Renaldi adalah siswa berkebutuhan khusus di SMPN 2 Banyuwangi. Ia dirundung oleh tujuh temannya dikarenakan tubuhnya yang tidak sempurna. Bahkan Renaldi sempat dipukul di bagian kepala dengan gagang pengambil sampah hingga ia terluka parah.

Dalam kasus perundungan yang terjadi pada remaja dengan disabilitas, perundungan kerap muncul diawali dari ketidakmampuan lingkungan dalam memahami dan menerima perbedaan kondisi yang tampak dari diri penyandang disabilitas. Akibat hambatan yang dimilikinya, mereka sering kali diejek, dipandang aneh, ditakuti, ditolak, bahkan diperlakukan semena-mena. Orang-orang dengan gangguan perkembangan ini kemudian mengalami tekanan sehingga memiliki perasaan rendah diri akibat kekurangan yang dimilikinya (Hallahan, 2006).

Dalam interaksi murid disabilitas di lingkungan sekolah, selain karena fisik yang berbeda, mereka juga dinilai menghambat proses pembelajaran di dalam kelas karena perilakunya yang berbeda. Hal tersebut juga menjadi pemicu adanya perundungan dikarenakan gaya belajar murid disabilitas cenderung berbeda dari murid lain termasuk dalam kemampuan menangkap pelajarannya yang terkadang lebih lambat (Dulisanti, 2015).

Data Susenas 2012 mencatat bahwa terdapat 2,45 persen penduduk Indonesia penyandang disabilitas. Data (RI, 2013) mengungkapkan bahwa prevalensi penduduk Indonesia dengan disabilitas sedang sampai sangat berat adalah 11 persen. Selain itu, tunadaksa adalah jenis disabilitas tertinggi di Indonesia dengan penyandang sebanyak 717.312 jiwa atau setara dengan 33,74 persen. 
Mengacu pada data kasus perundungan pelajar dengan disabilitas, tunadaksa adalah salah satu jenis disabilitas yang beberapa kali diberitakan menjadi korban. Janus (2009) mengungkapkan bahwa kecacatan sejak kecil dan perlakuan perundungan secara terus-menerus akan merusak self-efficacy, psikologis, dan sosial penyandang tunadaksa. Remaja penyandang tunadaksa yang menjadi korban perundungan lebih berisiko mengalami berbagai tekanan, baik secara fisik maupun psikologis. Hasil studi yang dilakukan (Center, 2002) menunjukkan bahwa perundungan dapat membuat remaja yang menyandang tunadaksa akan merasa cemas, malu akan kondisi fisik mereka, ketakutan, dan memengaruhi konsentrasi belajar di sekolah. Jika dibiarkan secara terus-menerus, hal tersebut akan menuntun mereka untuk menghindari sekolah. Bila perundungan berlanjut dalam jangka waktu yang lama, maka akan memengaruhi self-esteem individu, meningkatkan isolasi sosial, memunculkan perilaku menarik diri, dan menjadikan penyandang tunadaksa rentan terhadap stres dan depresi, serta merasa insecure, bahkan bisa membunuh atau melakukan bunuh diri (Riauskina, 2005).

Pemaparan di atas menyatakan bahwa perundungan memiliki dampak yang cukup besar terhadap remaja penyandang tunadaksa, baik dari segi fisik maupun psikologis. Pernyataan tersebut diperkuat oleh penelitian dari Bond (2001) yang menunjukkan bahwa perasaan malu, cemas dan depresi dari penyandang tunadaksa disebabkan oleh perilaku perundungan. Penelitian dari Houbre (2006) juga mengungkapkan bahwa sebanyak 76 persen penyandang tunadaksa yang pernah menjadi korban perundungan mengalami post-traumatic stress disorder. Dalam penelitian-penelitian tersebut, korban yang pernah mengalami perundungan sebagian besar adalah anak dan remaja berusia 6 sampai 15 tahun.

Sikap yang muncul dari individu bukan penyandang disabilitas terhadap individu penyandang disabilitas adalah apa yang dilihat terhadap keterbatasan individu disabilitas. Salah satunya adalah pada individu penyandang tunadaksa (cacat fisik). Dalam hal ini, individu bukan penyandang disabilitas bisa menunjukkan sikap positif dan negatif. Sikap positif biasanya cenderung menerima kehadiran individu penyandang tunadaksa tersebut dengan beberapa kekurangannya baik secara fisik maupun sosioemosional sehingga perlakuan tersebut adalah untuk menghindari penolakan bagi individu dengan disabilitas terutama tunadaksa. Perundungan sering terjadi pada individu yang terlihat lemah dan tidak dapat melindungi diri sendiri sehingga dampak yang didapat korbannya sangat membekas baik secara fisik maupun psikologis (Sullivan, 2004).

Dampak dari perundungan terhadap individu penyandang disabilitas (tunadaksa) adalah stres yang cenderung berkepanjangan (Bond, 2001). Namun demikian, data lain menunjukkan bahwa tidak semua individu remaja tunadaksa terjebak lama dalam situasi tersebut. Beberapa di antaranya mampu bangkit kembali secara psikologis setelah mengalami beberapa penolakan. Salah satu contoh individu yang mampu bangkit kembali secara psikologis setelah mengalami beberapa penolakan adalah Sekar, seorang remaja asal Malang. Sekar adalah murid di salah satu sekolah inklusif di Malang. Ia menyandang tunadaksa sejak usia 5 tahun karena kecelakaan dan tidak bisa berjalan. Sekar pernah mengalami beberapa kali penolakan dari teman-temannya karena fisiknya yang tidak seperti layaknya anak-anak seusianya. Sekar pernah dikucilkan oleh teman-teman sekelasnya hingga tidak ada yang mau berteman dengannya saat itu. Beberapa guru pun mendiskriminasinya karena mereka menganggap Sekar berbeda dari teman-temannya yang lain. Sekar pernah mengalami keterpurukan dan kecil hati namun kemudian ia berproses untuk bangkit dari tekanan yang dialaminya dan melawan hambatan yang dimiliki agar bisa berprestasi walaupun dalam keadaan yang terbatas (Anggraeni, 2006).

Individu yang mengalami peristiwa traumatis dapat memberi reaksi yang berbeda-beda. Apakah ia akan terus terpuruk dengan kondisi yang dialaminya, atau individu tersebut mampu menyesuaikan diri dengan kondisi yang dihadapinya dan bangkit dari keterpurukan atau menjadi kuat dalam menghadapi peristiwa traumatis tersebut. Penyesuaian yang membuat individu ini mampu kembali bangkit dari situasi negatif tersebut disebut dengan resiliensi (Chandra, 2007).

INSAN Jurnal Psikologi dan Kesehatan Mental

Tahun 2020, Vol. 5(1), 13-20

doi: 10.20473/jpkm.v5i12020.13-20 
Resiliensi merupakan kemampuan untuk bertahan dan beradaptasi serta kapasitas manusia untuk menghadapi dan memecahkan masalah setelah mengalami kesengsaraan (Hendriani, 2013). Definisidefinisi tersebut masuk ke dalam komponen resiliensi atau yang biasa disebut dengan sumber resiliensi (Hendriani, 2013).

Terdapat tiga sumber resiliensi menurut Grotberg (dikutip dalam Hendriani, 2013), yaitu I am, I have, dan I can. Resiliensi dapat ditingkatkan dengan dukungan diberikan ( I have), ketika kekuatan dari dalam diri seperti kepercayaan diri, sikap yang optimis, sikap untuk menghargai dan empati dikembangkan ( $I$ am), dan ketika kemampuan interpersonal dan memecahkan masalah diperoleh (I can).

Berdasarkan rangkaian penjelasan di atas, peneliti bermaksud mendalami bagaimana remaja tunadaksa yang pernah mengalami perundungan dapat menjadi resilien, dan bagaimana gambaran resiliensi yang dimiliki individu tersebut. Hal ini perlu dikaji agar siswa, orang tua, dan pihak sekolah memiliki kesiapan untuk menghadapi perundungan pada siswa dengan kebutuhan khusus, terutama pada penyandang tunadaksa. Dengan memiliki kesiapan yang diperlukan, diharapkan dampak negatif yang ditimbulkan oleh perundungan dapat dicegah.

\section{E T O D E}

\section{Desain Penelitian}

Penelitian ini menggunakan pendekatan kualitatif dengan tipe penelitian studi kasus intrinsik. Penulis memilih pendekatan kualitatif karena untuk menggali secara mendalam keunikan yang terjadi pada masing-masing remaja tunadaksa yang mengalami perundungan dalam melakukan resiliensi. Penulis juga memilih menggunakan studi kasus intrinsik untuk memahami kondisi pada penelitian ini secara utuh tanpa ada tujuan untuk menghasilkan konsep atau teori ataupun tanpa adanya upaya untuk melakukan generalisasi.

\section{Partisipan}

Partisipan dalam penelitian ini dipilih dengan teknik purposive berdasarkan kriteria-kriteria yang ditentukan oleh penulis, yaitu partisipan remaja berusia 12-15 tahun, partisipan adalah penyandang tunadaksa (cacat fisik), partisipan pernah mengalami perilaku perundungan,

\section{Prosedur}

Partisipan menunjukkan sebagai individu resilien yang ditunjukkan melalui metode screening, partisipan tidak keberatan dan bersedia untuk menjadi partisipan dalam penelitian ini sesuai dengan yang tertulis dalam lembar informed consent.

\section{Teknik Penggalian Data}

Teknik penggalian data dilakukan melalui proses wawancara secara mendalam.

\section{Analisis Data}

Hasil yang diperoleh kemudian dianalisis menggunakan teknik analisis tematik. Pengujian kredibilitas yang digunakan penulis pada penelitian ini menggunakan metode triangulasi, dimana untuk

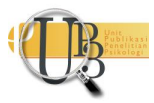


mendapatkan informasi tambahan terhadap partisipan penulis melakukan wawancara pada orang terdekat partisipan.

\section{H A S I L P E N ELIT IAN}

Hasil dari penelitian ini menunjukkan bahwa masing-masing partisipan menunjukkan coping stress yang berbeda untuk menunju resiliensi. Ketiga partisipan memiliki kondisi dan pengalaman serupa, yaitu seorang penyandang tunadaksa dan pernah mengalami kejadian perundungan, namun ketiganya berbeda menghadapi kejadian perundungan tersebut. Grotberg (1999) menyebutkan bahwa resiliensi memiliki 3 sumber yaitu I am, I have, dan I can. Ketiga sumber tersebut kemudian memiliki beberapa indikator yang menunjukkan bahwa seorang individu dapat dikatakan ber-resiliensi.

Dimensi I am pada salah satu indikator banyaknya orang yang menyayangi dan mendukung. Partisipan 1 dan 2 memiliki orang tua, guru, dan teman dekat yang mereka percayai untuk berbagi cerita. Sedangkan partisipan 3 hanya memiliki ibu karena ayahnya meninggal dunia saat kecelakaan sebelum partisipan mengalami ketunadaksaan. Selain itu, partisipan 3 juga memiliki teman dekat yang ia percayai untuk berbagi cerita. Hasil penelitian ini menunjukkan bahwa ketiga partisipan memiliki hasil yang hampir sama pada setiap indikator dalam dimensi I am.

Di salah satu indikator, memiliki struktur dan aturan yang diberlakukan dalam rumah tangga pada dimensi I have. Hanya partisipan 1 dan 2 yang memenuhi indikator tersebut. Lingkungan keluarga selalu menerapkan ajaran agama pada partisipan 1 dan 2, dan hal tersebut telah menjadi kebiasaan yang positif untuk mereka. Berbeda dengan partisipan 1 dan 2, partisipan 3 tidak memiliki struktur dan aturan dalam rumahnya, ia lebih mengungkapkan coping stress-nya dengan mendengarkan lagu dan menyanyi yang merupakan hobinya.

Kemudian dimensi I can pada indikator kemampuan dalam memecahkan masalah hampir memiliki persamaan pada setiap partisipan. Ketika mengalami perundungan, ketiga partisipan tidak membalas perlakuan tersebut dan lebih memilih mengalah atau diam dengan tujuan agar perlakuan perundungan tersebut dapat berkurang. Selain itu, pada partisipan 2 menempuh penyelesaian masalahnya dengan beribadah dan menceritakan kejadian yang mengganggunya kepada orang yang ia percayai agar ia merasa tenang.

\section{I S K U S I}

Pada penelitian ini, penulis mendapati ketiga partisipan memiliki perbedaan dalam menunjukkan setiap indikator pada masing-masing dimensi. Meski sama-sama penyandang tunadaksa, ketiga partisipan penelitian ini mengalami ketunadaksaan dalam kondisi yang berbeda. Partisipan 1 mengalami ketunadaksaan sejak ia berusia 6 bulan. Saat itu ia menderita sakit panas dan tubuhnya yang tidak kuat untuk menahan sehingga ia kejang. Hal ini berimbas pada syarafnya dan mengakibatkan kelumpuhan. Partisipan 2 mengalami ketunadaksaan sejak ia lahir karena terdapat salah satu syarafnya yang terganggu dan mengakibatkannya tidak bisa berjalan. Sedangkan partisipan 3 mengalami ketunadaksaan sejak ia berada di bangku SD karena kecelakaan yang ia alami bersama dengan ayahnya. Kecelakaan tersebut dan mengakibatkan ayahnya meninggal dunia dan ia mengalami kelumpuhan.

Pada dimensi yang berkaitan dengan kekuatan pribadi dalam diri individu ( $\mathrm{am}$ ), ketiga partisipan sama-sama memiliki banyak orang yang menyayangi dan mendukungnya mulai dari orang tua hingga orang-orang yang selalu ada untuknya. Ketiga partisipan juga dapat mencintai, ikut merasakan apa yang orang lain rasakan, dan mempunyai rasa peduli terhadap apa yang terjadi pada orang lain. Perbedaannya terletak pada pengalaman dan pribadi partisipan. Partisipan 1 dan 3 mempunyai rasa

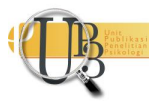


peduli terhadap apa yang terjadi pada orang lain, pernyataan tersebut terlihat dari cita-cita dan pengalaman mereka. Sedangkan partisipan 2 terlihat dari pribadi partisipan sendiri yang merupakan seorang individu yang memiliki hati yang lembut (tidak tegasan).

Rasa bangga pada diri sendiri juga dimiliki oleh ketiga partisipan namun ketiganya berbeda dalam apa yang ia banggakan. Partisipan 1 memiliki rasa bangga akan dirinya melalui kemandiriannya dalam melakukan aktivitasnya sehari-hari yang tidak semua remaja bisa melakukan aktivitasnya dengan mandiri seperti yang biasa ia lakukan. Partisipan 2 menunjukkan rasa bangga akan dirinya melalui tekadnya yang pantang menyerah di tengah keterbatasannya. Sedangkan partisipan 3 memiliki rasa bangga akan dirinya melalui usahanya dalam memenangkan perlombaan menyanyi yang pernah ia ikuti. Kemudian indikator mempunyai rasa percaya diri, keyakinan dan mempunyai banyak harapan juga dimiliki oleh ketiga partisipan melalui cita-cita yang mereka yakini bahwa suatu saat akan terwujud. Perbedaannya terletak pada partisipan 3 yang menunjukkan rasa percaya diri, keyakinan, harapannya melalui orang-orang yang mendukungnya di tengah keterbatasan fisik yang ia alami. Ia yakin dan percaya bahwa di tengah keterbatasan fisiknya, masih banyak orang yang akan mendukungnya.

Selain itu perbedaan juga terlihat dalam dimensi dukungan sosial dari lingkungan di sekitar individu (I have). Pada indikator mempunyai kepercayaan penuh dalam menjalani sebuah hubungan, ketiganya memiliki perbedaan yang signifikan. Kepercayaan penuh melalui dukungan-dukungan kecil dari orangorang di sekitar hingga menimbulkan rasa percaya untuk menjalani sebuah hubungan dimiliki oleh partisipan 1. Berbeda dengan partisipan 1, partisipan 2 memiliki kepercayaan penuh dalam menjalani sebuah hubungan yang ditunjukkannya melalui hubungannya dengan pelaku perundungan. Saat ini, keduanya berteman baik dan partisipan 2 meyakini bahwa pelaku perundungan tidak akan melakukan perundungan lagi terhadapnya, dan keduanya memiliki rasa percaya dalam menjalin pertemanan. Sedangkan partisipan 3 menunjukkan kepercayaannya dalam menjalin sebuah hubungan melalui kelekatannya dengan ibunya. Partisipan 3 menjelaskan bahwa ibunya adalah orang yang selama ini paling ia percaya untuk berbagi cerita. Lebih lanjut, tidak semua partisipan memiliki struktur dan aturan yang diberlakukan dalam rumah tangga. Hanya partisipan 1 dan 2 yang memiliki indikator tersebut. Keduanya sama-sama menerima ajaran agama oleh orang tuanya, dan ajaran tersebut menjadi kebiasaan baik bagi kedua partisipan untuk selalu taat beribadah dalam kondisi apa pun. Di sisi lain, partisipan 3 tidak memiliki struktur dan aturan yang diberlakukan dalam rumahnya.

Dari ketiga partisipan tersebut, resiliensi paling menonjol ditunjukkan oleh partisipan 3. Dimensi paling menonjolnya adalah dimensi yang berkaitan dengan kekuatan pribadi dalam diri individu ( $\mathrm{I}$ am). Bila dibandingkan dengan partisipan 1 dan 2, partisipan 3 lebih memiliki rasa percaya diri yang tinggi akan masa depannya. Berdasarkan pengalamannya, partisipan 3 pernah mengalami masa kelam dimana ia dirundung oleh lingkungannya yang saat itu belum bisa menerima kondisinya. Ia menceritakan kejadian tersebut kepada ibunya sambil menangis. Setelah mengetahui kejadian tersebut, ibunya memberikan motivasi dan semangat agar ia tidak menyerah akan keadaannya. Banyak semangat serta dukungan yang juga ia terima dari orang-orang di sekitarnya, bahkan yang tidak ia kenal ketika berada di tempat umum. Dukungan dan semangat dari ibu dan orang-orang di sekitarnya membuat partisipan 3 merasa bahwa masih banyak orang yang mau menerima kondisinya, yang mana menjadikan partisipan 3 dapat ber-resiliensi hingga hari ini. Partisipan 3 juga sangat yakin meskipun dengan kondisi yang kurang sempurna, ia akan mewujudkan cita-citanya untuk menjadi seorang guru ABK suatu saat nanti. Meskipun hanya memiliki seorang ibu yang mengasuhnya, namun kekuatan pribadi dalam dirinya (I $a m$ ) yang tinggi membuatnya untuk bisa bangkit dan menjadi resiliensi dari masa kelamnya. 


\section{S I M P U L A N}

Berdasarkan hasil penggalian data dan pembahasan yang telah diuraikan, setiap partisipan memiliki keunikan tersendiri. Dalam melewati masa sulitnya, setiap partisipan menunjukkan resiliensinya dengan baik. Cara-cara yang diambil untuk dapat ber-resiliensi beberapa di antaranya adalah dengan melakukan coping stress seperti menceritakan setiap permasalahannya kepada orang yang dapat dipercaya, beribadah, bersikap cuek, menangis, dan mendengarkan lagu agar merasa lebih tenang. Semua partisipan memiliki faktor pendukung yang hampir sama yaitu dari social support seperti motivasi yang di dapatkan dari orang-orang di sekitarnya (orangtua, keluarga, sahabat). Partisipan 1 dan 2 juga diajarkan mengenai religiusitas yang ditanamkan oleh keluarga partisipan.

Perbedaan dari ketiga partisipan terlihat dari faktor penghambat yang hanya dimiliki oleh partisipan 3. Partisipan 1 dan 2 merasa tidak memiliki hambatan dalam melakukan resiliensi. Dalam melakukan resiliensi, ketiga partisipan memiliki perbedaan pada setiap sumber resiliensi yang ada ( $I$ am, I have, I can). Dari ketiganya, partisipan 3 adalah yang paling menonjol dalam ber-resiliensi dengan dimensi kekuatan dalam dirinya ( $\mathrm{I} \mathrm{am}$ ) sebagai sumber resiliensi terkuat. Meskipun demikian, dapat dikatakan bahwa ketiga partisipan telah bangkit dari masa sulitnya dan dapat ber-resiliensi dengan baik.

Mengetahui maraknya kejadian perundungan yang terjadi, khususnya pada individu disabilitas, peneliti mengimbau kepada masyarakat untuk menegur pelaku perundungan agar tidak melakukan tindakan tersebut di kemudian hari. Selain itu, saran yang diberikan penulis untuk penelitian selanjutnya agar dapat memfokuskan pada teori dari tokoh lain untuk memperkaya informasi mengenai resiliensi dan melihatnya dari sudut pandang yang berbeda.

\section{UCAPA N TERIMA KASIH}

Penyusunan artikel penelitian ini tidak terlepas dari dukungan dan doa dari beberapa pihak sehingga penulis ingin mengucapkan terima kasih kepada Ibu Wiwin Hendriani selaku dosen pembimbing skripsi Departemen Pendidikan dan Perkembangan Fakultas Psikologi Universitas Airlangga yang telah banyak membantu mengarahkan dan membimbing penulis dalam menyelesaikan penelitian ini. Terimakasih juga untuk orangtua, keluarga, serta sahabat dari penulis yang selalu setia mendoakan dan memberikan dukungan yang tiada henti sehingga penulis dapat menyelesaikan penelitian ini. Penulis juga mengucapkan terima kasih kepada seluruh partisipan yang telah bersedia untuk meluangkan waktunya dan berpartisipasi dalam penelitian ini.

\section{DEKLARASI POTENSI TERJADINYA KONFLIK KEPENTINGAN}

Melinda Oviyanti tidak bekerja, menjadi konsultan, memiliki saham, atau menerima dana dari perusahaan atau organisasi mana pun yang akan mengambil untung dari naskah ini, dan telah mengungkapkan bahwa ia tidak memiliki afiliasi selain yang telah disebut di atas. 


\section{PUSTAKA ACUAN}

Anggraeni, R. (2006). Skripsi. Resiliensi pada Penyandang Tunadaksa Pasca Kecelakaan.

Bond, L., Carlin, J. B., Thomas, L., Rubin, K., \& Patton, G. (2001). Does bullying cause emotional problems? A prospective study of young teenagers. BMJ, 323(7311), 480-484. https://doi.org/10.1136/bmj.323.7311.480

Center, N. Y. (2002). Facts for Teens: (online). Retrieved from http://www.safeyouth.org

Chandra, S. (2007). Resiliensi. Diakses melalui https://rumahbelajarpsikologi.com/index.php/konsepumum-mainmenu-31/resiliensi-mainmenu-92.

Dulisanti, R. (2015). Studi Kasus pada Proses Pendidikan Inklusif di SMK Negeri 2 Malang. Penerimaan Sosial dalam Proses Pendidikan Inklusif, 52-60.

Grotberg, E. H. (1999). Tapping Your Inner Strength. California, US: New Harbinger.

Hallahan, D. P. (2006). Exeptional Learners: An introduction to special education 10th Ed. USA: Pearson Education, Inc.

Hendriani, W. (2013). Proses Resiliensi Individu dalam Perubahan Kondisi Fisik Menjadi Penyandang Disabilitas (Grounded Theory pada Penyandang Tunadaksa). Surabaya: Program Studi Doktor Ilmu Kesehatan, Fakultas Kesehatan Masyarakat Universitas Airlangga.

Houbre, B., Tarquinio, C., Thuillier, I., \& Hergott, E. (2006). Bullying among students and its consequences on health. European Journal of Psychology of Education, 21(2), 183-208. https://doi.org/10.1007/bf03173576

Indra, Z. (2015, April 28). Indonesia Ranking Kedua Sedunia . Diakses melalui Tribun Pekanbaru Online: http://pekanbaru.tribunnews.com/2015/04/28/indonesia-ranking-kedua-sedunia

Janus, A. L. (2009). Disability and the Transition to Adulthood. Social Forces, 88(1), 99-120. https://doi.org/10.1353/sof.0.0248

Magfirah, U. \&. (2008). Hubungan Antara Iklim Sekolah dengan Kecenderungan Perilaku . Diakses melalui http://setiabudi.ac.id/jurnalpsikologi/

News, A. (2009). Retrieved from https://abcnews.go.com/2020/TheLaw/school--epidemic-turningdeadly/story?id=11880841.

Dubreuil, J., \& Mcniff, E. (2010, October 29). Bullied to Death in America's Schools. Diakses pada 9 Maret 2020, dari https://abcnews.go.com/2020/TheLaw/school--epidemic-turningdeadly/story?id=11880841.

RI, K. (2013). Riset Kesehatan Dasar: Riskesdas. Jakarta: Balitbang Kemenkes RI.

Riauskina, I. I., Djuwita, R., \& Soesetio, S. R. (2005). Gencet-gencetan" di mata siswa/siswi kelas 1 SMA: Naskah kognitif tentang arti, skenario, dan dampak" gencet-gencetan". Jurnal Psikologi Sosial, 12(01), 1-13.

Sullivan, K. (2000). The Anti-bullying Handbook. Oxford, United Kingdom: Oxford University Press.

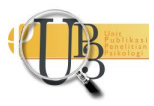

